\title{
An AHP Model Approach to Supply Chain Flexibility: A Case Study of Indian FMCG Firm
}

\author{
Rohit Kr Singh \\ ABV Indian Institute of Information Technology \& Management, Gwalior, India \\ E-mail: (Corresponding Author) \\ P. Acharya \\ ABV Indian Institute of Information Technology \& Management, Gwalior, India
}

\begin{abstract}
The current business environment is becoming increasingly uncertain, unpredictable and turbulent. Organizations always keep themselves ready to face any eventuality. Flexibility is one of the ways to cope up with uncertainty. Supply chain flexibility refers to the ability to change the supply chain system as per the current business need. The purpose of this paper is to identify the stage of supply chain which can help enhance its overall flexibility. Dimensions of supply chain flexibility are extracted from extant literature and their importance in the three stages of supply chain has been analysed based on the responses received during a survey carried out in an FMCG firm. An analytic hierarchy process (AHP) model has been developed. In this study 14 dimensions of supply chain flexibility are considered and these are grouped under the inbound, in-house and outbound stages of supply chain.
\end{abstract}

Keywords: supply chain, analytic hierarchy process, flexibility, FMCG

\section{INTRODUCTION}

Supply chain flexibility is ability of any organisation to respond to the changes that occurs frequently in the surrounding environment. Changes may occur in terms of customer requirement, change of location of customer, changes in government's business policies, implementation of new technology, volume changes as per product demand in market, design changes etc. The current business environment is becoming increasingly uncertain, unpredictable, and competitive as a result increasingly more complex (Singh and Acharya, 2013). Since last one decade it has been observed that customer demand is highly volatile and companies that are able to create values for their customers by satisfying their needs and wants generally increase their market share and their profitability. Thus an important part of any business, certainly for any supply chain, is making it easy for customers to do business with. In order to be competitive, some of the Indian manufacturing industries have already started implementing flexibility in different segments of the SC by several means and ways.

Flexibility has been considered as a major determinant of competitiveness in an increasingly intense competition in the marketplace. Today customers don't buy standard product rather they go for customized one (Pujawan, 2004).
For firms it's not easy always to manufacture product what customer wants with rigid manufacturing and rigid network of supply chain. Flexibility here comes into picture that helps firms to go for customization and make reach of product to customers place as per their expectation. There is no. of supply chain flexibility framework developed by various researchers. Here authors have extracted dimensions of supply chain flexibility from extensive literature review that are fir for an FMCG firm and then prioritize them with the help of analytic hierarchy process. An effective supply chain is usually characterized by its flexibility towards its operations which is commonly enabled through integrated information technology (Huang et al., 2010).

The main reason of acquiring flexibility concepts in Indian FMCG industry is customer highly volatile demand. In the interactive session with case firm's experts it has been found out that because of changing customer's taste, they need to change the variant of products, packaging material colour or add something new that makes product fresh in the industry. New product development is the key to success in today's competitive business environment. The other reason being the less entry barrier in the industry, and firm need to manage the competition with not only existing well known brand but with the new entrants also. Apart from it companies are facing competition with local FMCG product manufacturers also, local manufacturer's offers product in low price and captures mainly rural market.

Although rural market is having 50\% share in buying FMCG products but the pattern shows either they prefer to go for local brand or cheap priced product of well known brand. Still rural market is untapped for many well known FMCG brand. It requires highly robust and flexible distribution network that costs less and can help in position the other FMCG products in rural market.

\section{STUDIES ON SUPPLY CHAIN FLEXIBILITY}

Concept of flexibility comes into existence in 1980's and it was confined to manufacturing flexibility only. Later on firms realised that to cope up with uncertainty, there is a need to adopt flexibility throughout the supply chain. Firms throughout the worlds has started adopting flexibility concepts in their respective supply chains, and in India some of the firms have already adopted that, still many of the firms especially FMCG firms in India needs variety of 
research before adopting concepts of flexibility. Here in this study authors tried to prioritize the flexibility dimensions for an Indian FMCG firm.

Chan et al. (2009) worked on the issues surrounding flexibility and adaptability in supply chain management from an industrial practitioner and author believes that flexibility is certainly useful in inventory management of any supply chains. Here the issue of inventory management is critical because FMCG organizations need to have a proper amount of inventory because of their high product demand in market. Kumar et al. (2008) prepared a hierarchy of supply chain flexibility dimensions using interpretive structure modelling to know their influence over each other in global supply chains. Soon and Udin (2010) made an attempt to investigate supply chain management practices related to flexibility, value chain and capabilities and finds out all the organizations enhanced their manufacturing flexibility components with supply and logistic networks in order to be responsive to customers and gain tangible benefits. Singh and Acharya (2013) made an attempt to build a theoretical framework of supply chain flexibility; authors extracted twenty two flexibility dimensions from literature and made them fit into a broader framework. Study also identifies the various dimensions of supply chain flexibility and how they are catering to the inbound, inhouse and outbound stage of supply chain.

\subsection{Dimensions of Supply Chain Flexibility}

1-Product Flexibility- Product flexibility can be defined as the amount of responsiveness (or adaptability) for any future change in a product design, including new products and derivatives of existing products (Singh and Acharya, 2013).

2-Volume flexibility- According to Singh and Acharya (2013) it is the ability to produce above/below the installed capacity for a product. Volume flexibility enables organisation to manage their production plan and also enables to produce more while demand is high and low in case of low demand.

3-Transhipment Flexibility- It is the ability of organisation to transfer the products among stocking locations through replenishment strategies wherever and whenever it is needed (Singh and Acharya, 2013). Transhipment flexibility enables organisation to make product available in all stocking locations.

4-New Product Development /Launch Flexibility- Ability of an organisation to make new products in terms of new design, new specification and new style in order to fulfil the current requirement of customers. Launch flexibility also enables organisation to spread its wings in diversified product range.

5-Sourcing- This flexibility dimension enables organisation to keep more than one supplier of a particular product. So in case of any urgency or sudden rise in demand can be fulfilled easily. Also it gives parent firm one alternative and enhance purchasing power over its suppliers.

6-Physical Distribution Flexibility- Distribution flexibility as the ability to change distribution processes in an efficient or effective manner to adjust to requirements of both direct and indirect customers (Yu et al, 2012)

7-Demand Management Flexibility- It is the ability of a firm to quickly and effectively respond to the variety of customer needs for service, delivery time, and price (Zhang et al, 2002)

8-Coordination Flexibility- Coordination flexibility works towards development and maintaining the relationship with suppliers, intra-department relationship in a firm and with customers.

9-Logistics Flexibility- This is the ability of a firm to respond quickly and efficiently to changing customer needs in inbound and outbound delivery, support, and services (Zhang, 2005)

10-Manufacturing Flexibility- Manufacturing flexibility has the capability to provide organisations with the ability to change levels of production rapidly, to develop new products more quickly and more frequently, and to respond more rapidly to competitive threats (Oke, 2005)

11-Information System Flexibility- Information systems flexibility can be defined as the ability of an organization's collective information system to adapt and support changing requirements of the business functions such as product development, sourcing, manufacturing and logistics, and other strategic goals (Kumar et al., 2008)

12-Delivery Flexibility- Delivery flexibility enables organisation to fix the delivery of the product as per customer's wish and make reach of product in minimum possible time by selecting the appropriate way to deliver the product.

13-Access Flexibility- Access flexibility is the ability to provide a widespread or intensive distribution coverage, which is facilitated by the close co-ordination of downstream activities in the supply chain whether performed internally or externally (Sa'nchez and Pe'rez, 2005)

14-Process Flexibility- Process flexibility of each supply chain plant, concerning the number of product types that can be manufactured in each production site (Sa'nchez and Pe'rez, 2005).

Table 1 Dimensions of Supply Chain Flexibility

\begin{tabular}{|c|l|l|}
\hline No. & \multicolumn{1}{|c|}{ Dimension } & \multicolumn{1}{c|}{ Author(s) } \\
\hline 1 & Product & $\begin{array}{l}\text { Sa'nchez and Pe'rez (2005), Kumar et al. (2006), Parker \& Wirth (1999), Vickery et al. (1999), Stevenson } \\
\text { and Spring (2007) }\end{array}$ \\
\hline 2 & Volume & Sa'nchez and Pe'rez (2005), Stevenson and Spring (2007), Parker \& Wirth (1999), Vickery et al. (1999) \\
\hline 3 & Transhipment & Sa'nchez and Pe'rez (2005) \\
\hline 4 & $\begin{array}{l}\text { New product development/ } \\
\text { Launch Flexibility }\end{array}$ & Kumar et al. (2006), Vickery et al. (1999), Ndubisi et al. (2005), Sa'nchez and Pe'rez (2005) \\
\hline
\end{tabular}


Table 1 (continued)

\begin{tabular}{|c|l|l|}
\hline No. & \multicolumn{1}{|c|}{ Dimension } & \multicolumn{1}{c|}{ Author(s) } \\
\hline 5 & Sourcing & Sa'nchez and Pe'rez (2005), Kumar et al. (2006), Candace et al. (2011) \\
\hline 6 & Physical Distribution Flexibility & $\begin{array}{l}\text { Yu et al. (2012), Zhang et al. (2002, 2005), Vickery et al. (1999), Cooper et al. (1997), Lambert et al. } \\
(1998)\end{array}$ \\
\hline 7 & Demand Management Flexibility & Yu et al. (2012), Zhang et al. (2002), Lee (2001), \\
\hline 8 & Coordination Flexibility & Yu et al. (2012), Wilson and Platts (2010) \\
\hline 9 & Logistics & Cunningham (1996), Sa'nchez and Pe'rez (2005), Zhang et al. (2005), Stevenson and Spring (2007) \\
\hline 10 & Manufacturing & Slack (1983,1987), Kathuria (1998), Oke (2005), Yazici(2005) \\
\hline 11 & Information System & Stevenson and Spring (2007) \\
\hline 12 & Delivery & Sa'nchez and Pe'rez (2005), Kumar et al. (2006), Stevenson and Spring (2007) \\
\hline 13 & Access & Sa'nchez and Pe'rez (2005), Hua et al. (2009) \\
\hline 14 & Process & Parker \& Wirth (1999), Sa'nchez and Pe'rez (2005), Stevenson and Spring (2007) \\
\hline
\end{tabular}

\subsection{Indian FMCG Sector}

FMCG product manufacturers are operating in a highly volatile environment where product specifications and their demand are fluctuating on daily basis. Firm cannot change its manufacturing system entirely to cater with the changing needs, as it costs a lot (Singh and Acharya, 2014). Indian FMCG sector is fourth largest sector in the economy with the total market size of $\$ 2,229.1$ million. Use of flexibility concepts in FMCG sector is essential to cope up with uncertainties like changing demands at rapid rate, external pressure to reduce cost, easy entry for new comers to set up their business etc. There is high pressure on companies to increase profit and at the same time the customers are demanding lower prices (Pettersson and Segerstedt, 2013). Table 2 shows statistics regarding to Indian FMCG sector.

Table 2 Indian FMCG Sector at a Glance

\begin{tabular}{|l|l|}
\hline Market size & $\$ 2,229.1$ million \\
\hline Market volume & $6,336.0$ million units \\
\hline Market value forecast (2017) & $\$ 3,712.1$ million \\
\hline Market volume forecast (2017) & $8,479.5$ million units \\
\hline
\end{tabular}

\section{THE ANALYTIC HIERARCHY PROCESS METHODOLOGY}

In this study authors have used analytic hierarchy process to prioritize the stages of supply chain as well as flexibility dimensions associated with each stage of supply chain. AHP is a tool to find the optimal outcome from a multiple criteria scenario by employing a hierarchal approach to arrive at best solution. Singh (2013) discussed the various phases of AHP:

- $\quad$ Structuring the problem and building AHP model

Collecting data from expert interviews

- Determining the normalized priority weights of individual factors and sub factors

- $\quad$ Synthesis finding solution to problem

- $\quad$ Prioritizing the factors for Flexible Supply Chain Usin AHP

As Singh (2013) suggested in the first phase a theoretical construct of overall methodology is designed that consist of all the factors and sub factors of the study. The goal of this study is to prioritize the dimensions of flexible supply chain, so is placed on level-1 and on level-2 main factors or 3 stages of supply chain are placed i.e. inbound, in-house and outbound stages of supply chain. At the next level all the dimensions of flexible supply chain are placed and linked with its respective supply chain stage. And finally on last level we get flexible supply chain. Second phase is all about data collection, for this study a team of case firm executives, all having experience of more than 10 years participated in giving scores to various matrices. The 9 point scale was used for pair wise comparison. In the next phase normalised weights matrices are obtained.

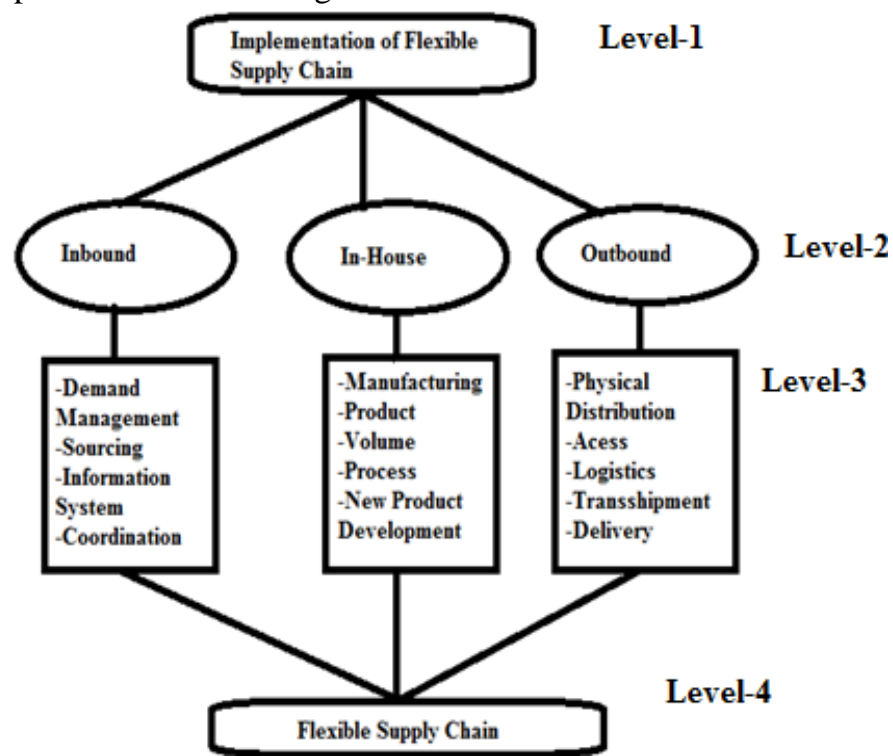

Figure 1 Prioritizing Factors for Flexible Supply Chain Using AHP

Table 3 Saaty's Nine-Point Scale for AHP

\begin{tabular}{|l|l|}
\hline Intensity of Importance & \multicolumn{1}{|c|}{ Meaning } \\
\hline 1 & Equal Importance \\
\hline 3 & Weak Importance of one over another \\
\hline 5 & Essential Important \\
\hline 7 & Demonstrated Importance \\
\hline 9 & Absolute Importance \\
\hline $2,4,6,8$ & $\begin{array}{l}\text { Intermediate values between the two } \\
\text { adjacent judgement }\end{array}$ \\
\hline Source: Saaty (1994) & \\
\hline
\end{tabular}




\subsection{Data Collection: An AHP Approach}

AHP helps the analysis to organize theoretical aspects of problem into a hierarchical structure similar to family tree. Likewise, Zahedi (1996), suggests several advantages of AHP including the ease of use and over specification of judgment, use of appropriate measurement scales and builtin consistency tests. Due to its mathematical simplicity and flexibility, AHP has been a favourite decision tool for research in many fields. Here Data collection is done by visiting one of the leading Indian FMCG firms, executives from various departments participated and provided us with the scores.

Table 4 Pairwise Comparison Matrix: Main Factors (Stages of Supply Chain)

\begin{tabular}{|l|l|l|l|}
\hline & Inbound & In- House & Outbound \\
\hline Inbound & 1 & $1 / 9$ & 5 \\
\hline In-House & 9 & 1 & $1 / 9$ \\
\hline Outbound & $1 / 5$ & 9 & 1 \\
\hline Total & 10.2 & 10.12 & 6.12 \\
\hline
\end{tabular}

Table 5 Normalised Weight Matrix: Main Factors (Stages of Supply Chain)

\begin{tabular}{|l|l|l|l|l|}
\hline & Inbound & In- House & Outbound & $\begin{array}{l}\text { Priority } \\
\text { Vector (PV) }\end{array}$ \\
\hline Inbound & 0.098 & 0.012 & 0.816 & 0.308 \\
\hline In-House & 0.882 & 0.099 & 0.019 & 0.334 \\
\hline Outbound & 0.019 & 0.889 & 0.164 & 0.357 \\
\hline
\end{tabular}

Table 6 Pairwise Comparison Matrix: Sub Factors of Inbound Stage

\begin{tabular}{|l|l|l|l|l|}
\hline & DM (a) & Sourcing & IS (b) & Coordination \\
\hline DM & 1 & $1 / 7$ & 9 & 6 \\
\hline Sourcing & 7 & 1 & 5 & 7 \\
\hline IS & $1 / 9$ & $1 / 5$ & 1 & $1 / 9$ \\
\hline Coordination & $1 / 6$ & $1 / 7$ & 9 & 1 \\
\hline Total & 8.278 & 1.485 & 24 & 8.12 \\
\hline
\end{tabular}

${ }^{\text {a }}$ Demand Management

${ }^{\mathbf{b}}$ Information System

Table 7 Normalised Weight Matrix: Sub Factors of Inbound Stage

\begin{tabular}{|l|l|l|l|l|l|}
\hline & DM & Sourcing & IS & Coord. & PV \\
\hline DM & 0.120 & 0.096 & 0.375 & 0.738 & 0.332 \\
\hline Sourcing & 0.845 & 0.673 & 0.208 & 0.862 & 0.647 \\
\hline IS & 0.112 & 0.135 & 0.041 & 0.013 & 0.075 \\
\hline Coordination & 0.166 & 0.097 & 0.375 & 0.123 & 0.190 \\
\hline
\end{tabular}

Table 8 Pairwise Comparison Matrix: Sub Factors of InHouse Stage

\begin{tabular}{|l|c|c|c|c|c|}
\hline & Manufactrg. & Product & Volume & Process & NPD \\
\hline Manufacturing & 1 & 7 & 8 & 5 & $1 / 7$ \\
\hline Product & $1 / 7$ & 1 & 3 & 5 & 4 \\
\hline Volume & $1 / 8$ & $1 / 3$ & 1 & 2 & 2 \\
\hline Process & $1 / 5$ & $1 / 5$ & $1 / 2$ & 1 & $1 / 6$ \\
\hline NPD & 7 & $1 / 4$ & $1 / 2$ & 6 & 1 \\
\hline Total & 8.467 & 8.783 & 13 & 19 & 7.309 \\
\hline
\end{tabular}

Table 9 Normalised Weight Matrix: Sub Factors of InHouse Stage

\begin{tabular}{|l|c|c|c|c|c|c|}
\hline & $\begin{array}{l}\text { Manu- } \\
\text { facturing }\end{array}$ & Product & Volume & Process & NPD & PV \\
\hline $\begin{array}{l}\text { Manu- } \\
\text { facturing }\end{array}$ & 0.118 & 0.796 & 0.615 & 0.263 & 0.019 & 0.362 \\
\hline Product & 0.016 & 0.113 & 0.230 & 0.263 & 0.547 & 0.233 \\
\hline Volume & 0.014 & 0.037 & 0.076 & 0.105 & 0.273 & 0.101 \\
\hline Process & 0.023 & 0.022 & 0.038 & 0.052 & 0.022 & 0.031 \\
\hline NPD & 0.826 & 0.028 & 0.038 & 0.315 & 0.136 & 0.268 \\
\hline
\end{tabular}

Table 10 Pairwise Comparison Matrix: Sub Factors of Outbound Stage

\begin{tabular}{|l|l|l|l|l|l|}
\hline & PD (c) & Access & Logistics & Transhipment & Delivery \\
\hline PD & 1 & $1 / 9$ & 9 & 7 & 5 \\
\hline Access & 9 & 1 & 9 & 4 & 5 \\
\hline Logistics & $1 / 9$ & $1 / 9$ & 1 & $1 / 6$ & $1 / 7$ \\
\hline Transhipment & $1 / 7$ & $1 / 4$ & 6 & 1 & $1 / 3$ \\
\hline Delivery & $1 / 5$ & $1 / 5$ & 7 & 3 & 1 \\
\hline Total & 10.453 & 1.672 & 32 & 15.167 & 11.476 \\
\hline
\end{tabular}

${ }^{c}$ Physical Distribution

Table 11 Normalised Weight Matrix; Sub Factors of Outbound Stage

\begin{tabular}{|l|l|l|l|l|l|l|}
\hline & PD & Access & $\begin{array}{l}\text { Logis- } \\
\text { tics }\end{array}$ & $\begin{array}{l}\text { Tranship- } \\
\text { ment }\end{array}$ & $\begin{array}{l}\text { Deli- } \\
\text { very }\end{array}$ & PV \\
\hline PD & 0.095 & 0.066 & 0.281 & 0.461 & 0.435 & 0.267 \\
\hline Access & 0.860 & 0.598 & 0.281 & 0.263 & 0.435 & 0.487 \\
\hline Logistics & 0.010 & 0.066 & 0.031 & 0.011 & 0.012 & 0.026 \\
\hline $\begin{array}{l}\text { Tranship } \\
\text {-ment }\end{array}$ & 0.013 & 0.149 & 0.187 & 0.065 & 0.029 & 0.088 \\
\hline Delivery & 0.019 & 0.119 & 0.218 & 0.197 & 0.087 & 0.128 \\
\hline
\end{tabular}

\section{RESULTS AND DISCUSSION}

In this study authors have taken fourteen dimensions of supply chain flexibility and three main stages of supply chain i.e inbound, in-house and outbound stages. To form the table of local and global weightage, firstly pair wise comparison judgement matrix was formed and this primary matrix formed the basis to determine the normalised weight.

Table 12 shows the local and global weightage of main factors (inbound, in-house and outbound stages of supply chain) and also of their respective sub factors. Outbound stage (0.357) of supply chain is considered as most critical stage to make firm's supply chain flexible followed by Inhouse (0.334) and Inbound stage (0.308). Flexibility of supply chain is most dependent on outbound stage as it interacts directly with customers and in this era where customer demand is highly volatile and also they want product in minimum possible time, sub stages or sub factors of outbound stages need to be flexible enough to cater the customer's demand. 
Table 12 Local and Global Weightage of Factors and Sub Factors

\begin{tabular}{|l|c|c|}
\hline \multicolumn{1}{|c|}{ Factors/Sub Factors } & Local weightage & Global weightage \\
\hline 1- Outbound Supply Chain & 0.357 & 0.357 \\
\hline Access & 0.487 & 0.173 \\
\hline Physical Distribution & 0.267 & 0.095 \\
\hline Delivery & 0.128 & 0.045 \\
\hline Transhipment & 0.088 & 0.031 \\
\hline Logistics & 0.026 & 0.009 \\
\hline \multicolumn{3}{|l|}{} \\
\hline 2- In-House Supply Chain & 0.334 & 0.334 \\
\hline Product & 0.547 & 0.182 \\
\hline Volume & 0.273 & 0.091 \\
\hline NPD & 0.136 & 0.045 \\
\hline Process & 0.022 & 0.007 \\
\hline Manufacturing & 0.019 & 0.006 \\
\hline \multicolumn{2}{|l|}{} \\
\hline 3-Inbound Supply Chain & 0.308 & 0.308 \\
\hline Sourcing & 0.647 & 0.199 \\
\hline Demand Management & 0.332 & 0.102 \\
\hline Coordination & 0.190 & 0.058 \\
\hline Information System & 0.075 & 0.021 \\
\hline
\end{tabular}

Outbound supply chain majorly deals in delivery and distribution process, minimum the lead time leads to higher the customer satisfaction and to achieve this all the activities in outbound supply chain should be well integrated internally and externally with other stages of supply chain. Among the sub factors of outbound supply chain Access flexibility (.487) comes to be the most important one followed by Physical distribution (0.267), Delivery (.128), Transhipment (.088), and Logistics (0.026). Access flexibility provides the widespread coverage and this is achieved by various distribution activities, it also helps firm to make its footprint in a place where it was non-existent previously. Distribution flexibility allows firms to adopt/ or make changes in its existing process in order to make reach of organisation's product to maximum number of people. And delivery flexibility means to change the process of delivery so that product reaches to its customer in minimum possible time.

In-house (0.334) supply chain comes out to be the second most important stage in order to make the entire supply chain a flexible one. To manage the activities of inhouse stage is completely in hand of parent organisation as in-house stage deals in activities happening inside the parent organisation only. Among the sub-factors product (0.547) comes out to be the most critical flexibility dimension. Customer would be satisfied if they get variety of products under the same brand, and they can purchase one as per their budget and other preferences. Volume (0.273) is next most important flexible dimension under in-house section, this flexible dimension helps organisation in manufacturing the exact quantity of product as per the demand in market. So, in case market demand of product is very high, firm must have ability to produce it. The next important dimension is New product development (0.136) followed by process (0.022) and Manufacturing (0.019).

And the last important stage of flexible supply chain is Inbound (0.308) Stage. This stage primarily deals in supplier relation and maintains the coordination between firm and suppliers. Among the sub factors sourcing flexibility (0.647) comes out to be the most important one. As sourcing flexibility enables firm to have more than one supplier of one product, so in case of access demands, firms is having one more supplier to fulfil demand also sourcing flexibility enables firm to have purchasing power over its suppliers. Next important dimension in inbound stage is demand management flexibility (.332) followed by coordination (0.190) and Information system (.075).

\section{CONCLUSION}

The current business environment is becoming increasingly uncertain, unpredictable, and competitive as a result increasingly more complex. In today's context flexibility in supply chains allows firms to grow at rapid rate, make reach to maximum number of customers and helps in avoiding any future disruption. The main reason of acquiring flexibility concepts in Indian FMCG industry is customer highly volatile demand. This paper has tried to identify different dimensions of supply chain flexibility through extensive literature review and tried to prioritize them through AHP. By this prioritization, firms will have an idea of flexibility dimensions having more impact or importance in achieving supply chain flexibility in organisation. Outbound stage of supply chain comes out to be the most important one followed by In-house stage and inbound stage.

\section{REFERENCES}

Candace Y. Yi, E.W.T. Ngai, and K-L. Moon (2011), Supply Chain Flexibility in an Uncertain Environment: Exploratory Findings from Five Case Studies, Supply Chain Management: An International Journal 16 (4), pp. 271 - 283.

Chan HK, Wang WYC, Luong LHS and Chan FTS (2009), Flexibility and Adaptability in Supply Chains, Supply Chain Management: An International Journal 14 (6), pp. 407-410.

Cooper, M.C., Lambert, D.M. and Pagh, J.D. (1997), Supply Chain Management: More Than a New Name for Logistics, International Journal of Logistics Management 8 (1), pp. 113.

Cunningham J.B. (1996), Designing Flexible Logistics Systems: A Review of Some Singaporean Examples, Logistics Information Management 9 (2), pp. 40 - 48.

Hua Song, Chatterjee Samir Ranjan, and Kang-kang Yu (2009), Access Flexibility, Trust and Performance in Achieving Competitiveness: An Empirical Study of Chinese Suppliers and Distributors, Journal of Chinese Economic and Foreign Trade Studies 2 (1), pp. $31-46$.

Huang JD, Hu, M.H. and Wee H.M. (2010), Lead Logistics Provider and Its Effect on Supply Chain Alliances - A Case Study on Taiwan Motor Industry, Operations and Supply Chain Management 3 (3), pp. 164-175.

Kathuria R. (1998), Managing for Flexibility: A Manufacturing Perspective, Industrial Management \& Data Systems 98 (6), pp. $246-252$.

Kumar P., Shankar R., and Yadav S. (2008), Flexibility in Global Supply Chain: Modeling the Enablers, Journal of Modelling in Management 3 (3), pp. 277 - 297. 
Kumar V., Fantazy K. A., Kumar U., and Boyle T. A. (2006), Implementation and Management Framework for Supply Chain Flexibility, Journal of Enterprise Information Management 19 (3), pp. $303-319$.

Lambert, D.M., Cooper, M.C. and Pagh, J.D. (1998), Supply Chain Management: Implementation Issues and Research Opportunities, International Journal of Logistics Management 9 (2), pp. 1-19.

Lee, H.L. (2001), Ultimate Enterprise Value Creation Using Demand-Based Management, Stanford Global Supply Chain Management Forum Working Paper Series, SGSCMF-W12001.

Ndubisi N. O., Jantan M., Hing L. C., and Ayub M.S. (2005), Supplier Selection and Management Strategies and Manufacturing Flexibility, Journal of Enterprise Information Management 18 (3), pp. 330 - 349.

Oke, A. (2005), A Framework for Analysing Manufacturing Flexibility, International Journal of Operations \& Production Management 25 (10), pp. 973-96.

Parker Rodney P., and Wirth Andrew (1999), Manufacturing Flexibility: Measures and Relationships, European Journal of Operational Research 118, pp.429-449

Pettersson, A.I and Segerstedt, A. (2013), To Evaluate Cost Savings in a Supply Chain : Two examples from Erricsson in the telecom industry, Operations and Supply Chain Management, 6 (3), pp. $94-102$

Pujawan, N. (2004), Assessing Supply Chain Flexibility: A Conceptual Framework and Case Study, International Journal of Integrated Supply Management 1 (1), pp. 79 - 97.

Sa'nchez, A.M. and Pe'rez, M.P. (2005), Supply Chain Flexibility and Firm Performance: A Conceptual Model and Empirical Study in the Automotive Industry, International Journal of Operations \& Production Management 25 (7), pp. 681-700.

Saaty, T.L. (1994), How to Make a Decision: The Analytic Hierarchy Process, Interfaces 24 (6), pp. 19-43.

Singh R.K and Acharya P. (2013), Supply Chain Flexibility: A Framework of Research Dimensions, Global Journal of Flexible Systems Management 14 (3), pp.157-166.

Singh R.K. (2013), Prioritizing the Factors for Coordinated Supply Chain Using Analytic Hierarchy Process (AHP), Measuring Business Excellence 17 (1), pp. 80-98.
Singh R.K and Acharya P. (2014), Identification and Evaluation of Supply Chain Flexibilities in Indian FMCG Sector Using DEMATEL, Global Journal of Flexible Systems Management 15 (2), pp.91-100.

Slack, N. (1983), Flexibility as a Manufacturing Objective, International Journal of Operations \& Production Management 3 (3), pp. 4-13.

Slack, N. (1987), The Flexibility of Manufacturing Systems, International Journal of Operations \& Production Management 7 (4), pp. 35-45.

Soon HQ and Udin MZ (2011), Supply Chain Management from the Perspective of Value Chain Flexibility: An Exploratory Study, Journal of Manufacturing Technology Management 22 (4), pp. 506-526.

Stevenson M and Spring M (2007), Flexibility from a Supply Chain Perspective: Definition and Review, International Journal of Operations \& Production Management 27 (7), pp. $685-713$.

Vickery, S., Dro"ge, C. and Markland, R. (1997), Dimensions of Manufacturing Strength in the Furniture Industry, Journal of Operations Management 15 (4), pp. 317-30.

Wilson S., and Platts K. (2010), How Do Companies Achieve Mix Flexibility?, International Journal of Operations \& Production Management 30 (9), pp. 978 - 1003.

Yazici H. J. (2005), Influence of Flexibilities on Manufacturing Cells for Faster Delivery Using Simulation, Journal of Manufacturing Technology Management 16 (8), pp. 825 841.

Yu K., Cadeaux J., and Song H. (2012), Alternative Forms of Fit in Distribution Flexibility Strategies, International Journal of Operations \& Production Management 32 (10), pp. 1199 1227.

Zhang, Q., Vonderembse, M.A. and Lim, J.S. (2002), Value Chain Flexibility: A Dichotomy of Competence and Capability, International Journal of Production Research 40 (3), pp. 561-83.

Zhang, Q., Vonderembse, M.A. and Lim, J.S. (2005), Logistics Flexibility and Its Impact on Customer Satisfaction, The International Journal of Logistics Management 16 (1), pp.71 $-95$

Rohit Kumar Singh has obtained his bachelor degree in Mechanical Engineering followed by his Master's degree in business administration from IIIT Gwalior. Currently he is pursuing his $\mathrm{PhD}$ in area of supply chain management from $\mathrm{ABV}$ Indian Institute of Information Technology \& Management Gwalior. His area of interest lies in operations and supply chain management and have published papers in national and international journals.

Padmanav Acharya is an Associate Professor in the Institute. Acharya has done his M.Tech and Ph.D. from IIT Kharagpur after his B.Tech in Mechanical Engineering from Utkal University. He has 18 years of teaching experience. Prior to joining ABV-IIITM, he was working as an Assistant Professor at IGIT, Sarang, Orissa. He has published several papers in Journals of international and national repute and also presented papers and chaired sessions at international and national conferences $\mathrm{He}$ has been a reviewer of prestigious international journals. His areas of interest include Software Engineering and Management, Busyness System Simulation, Operations Management. 